2. And must further show that the "little" examination has been passed, which can only be done in India. Or that the candidate has been dispensed from passing it. (The examination includes arithmetic, the elements of the Dutch language, and the proof of writing a good legible hand. The Governor-General regulates the conditions of this examination.)

For some of the highest posts, such as Vice-President and Member of the Council of the Netherlands Indies, President and members of the Chamber of Accounts, or Director of some Government Department, etc., etc., no diplomas of examinations are required. For these it is requisite-and indeed for allto be a Dutchman and to have reached a certain age, a condition which must also be fulfilled by many who occupy less important posts, for instance a large number of the law officers.

J. SPANJAARD.

(Translated from the Dutch by Mrs. Lzcky.)

\title{
Civil Service of India and other British Possessions in Asia.
}

It may be useful to recall in very broad outline the wellknown regulations of the India Civil Service. Before 1895 candidates had to present themselves for competitive examination between the ages of 17 and 19-and then spent two years at a University in England, Scotland, or Ireland, before the Final Examination, after which a successful candidate might obtain leave to spend a third year in study in England before going to India-the State paying $£$ I50 for his expenses each year.

It was found however that it was a mistake to select candidates at so early an age, and that the system was moreover a costly one. New rules were drawn up on a more economical and practical basis. The age of admission to the first competitive examination was raised to from $2 \mathrm{I}$ to 23 years. The candidates select their own subjects from English language and History, Greek, Latin, French, German, science, law, etc.-all the subjects in fact included in a liberal education. The examination is such that only the best pupils from schools or universities have any chance of success. 
Selected candidates then remain for a year on probation in England, studying Indian law and one Indian vernacular, and receive from the Government $£ 100$ if they spend their year at a University. The "Final Examination" at the end of the year in these subjects determines their place in the Indian Civil Service. They must also qualify in riding, for which the tests are fairly severe.

The candidate is allowed to choose, so far as is possible, the Province to which he will go; and after arriving in India he decides on which of the three branches of the Service he will specialize in-political agents and executive officers ; magistrates and judges; revenue controllers and administrators.

The Civil Services of Ceylon, Hong-Kong, the Straits Settlements, and the Malay States-all classed as Eastern Cadetshipsfollow the same general lines. The age however for entrance is from 21 to 24 years. Ceylon cadets study Singalese and Tamil for two years after arriving in Ceylon, and pass two exams. in language, law, and accounts. Cadets in the other dependencies study Malay, Chinese and Tamil.

There are special arrangements for the Indian Forest Service. For this candidates are examined early, at from seventeen to twenty years of age, and then study three years at the Royal Indian Engineering College, Cooper's Hill, for which the government pays $£ 6 \mathrm{I}$ for each of the seven terms, or $£ 427$. A further study in France or Germany is required, for which $£ 150$ is given.

\section{Administration of Africa.}

This highly organised Asiatic system has not been extended to Africa. After a century on the West Coast and twenty years in East and Centre, the arrangements are still of a rough and ready kind. In Crown Colonies, generally speaking, posts under $£ 200$ a year are given at the will of the Governor : while for posts over that sum he asks the approbation of the Secretary of State for his nominee, which is practically always given. Only the highest and permanent, "commissioned," grade of officials is appointed direct by the Colonial Office. There is no regular system of preferment. But the highest 
grade may be called a permanent service, and has a pension list.

The Foreign Office makes the civil appointments in the territories and protectorates under its control, on much the same plan as above sketched, except that the minor, "noncommissioned," appointments are usually made by the Crown Agents for the Colonies in London.

A certain number of young men who have failed in the Indian Civil Service work, naturally try their fortunes in the African service.

"This African Service," writes a resident in West Africa of twenty years, "is only made use of by the majority as a stepping-stone to a better Colonial appointment, in some other colony. We want a Service of our own, with men ready to devote their lives to the country and the people. Leave every year takes all the sting out of the climate, and .I can see no reason why, under these circumstances, the Service should not become popular to the right class of men. Continuity is everything in this work, and I would rather see men kept in the same place and their salaries raised according to the time they have served, than that they should be promoted to some other place to gain a higher salary."

A. S. G. 